\title{
Eugeniu Coșeriu \& Horst Geckeler, Orientări în semantica structurală, Traducere din limba engleză, notă preliminară, comentarii și postfaţă de Cristinel Munteanu, Editura Universității „Alexandru Ioan Cuza”, Iași, 2016, 217 p.
}

\author{
Dinu Moscal* \\ Institutul de Filologie Română „A. Philippide”, Str. Th. Codrescu 2, 700481 Iași, România
}

Traducerea textelor științifice de referință în mediul științific contemporan nu constituie, din nefericire, o tradiție în mediul științific românesc, așa cum se întîmplă de exemplu, în Italia sau Spania. Astfel se explică de ce în prezent apar traduceri ale unor texte valoroase, apărute cu destul de mult timp în urmă, aşa cum este cazul și pentru Orientări în semantica structurală. Textul din acest volum a apărut într-o primă versiune în anul 1974, apoi în volum, fără modificări substanțiale, în anul 1981 (vezi p. 13). Importanța sa este dată de statutul său de „dare de seamă” într-o ramură a lingvisticii aflate la apogeu, dar, în același timp, fără o direcție de cercetare care să constituie un punct de convergență pentru specialiști. Titlul (Orientări...) reflectă această stare a cercetării în domeniul semanticii.

Eugeniu Coșeriu și Horst Geckeler, discipolul său, fac acest raport al cercetărilor în domeniul semanticii structurale, printr-un text organizat în stilul cunoscut al lui Coșeriu, adică prin secțiuni şi subsecțiuni numerotate fără titluri. Traducătorul, Cristinel Munteanu, alege să dea un statut de capitole secțiunilor principale, dîndu-le și un titlu conform informației date de autori în primul paragraf al fiecărei secțiuni, ceea ce conferă un statut formal de volum unui text relativ scurt (p. 17-116). Desigur, prezentarea semanticii structurale poate fi făcută și într-o lucrare voluminoasă, însă scopul autorilor se rezumă la o prezentare succintă a istoricului, a direcțiilor de cercetare și a metodologiilor aferente. Lucrarea apare într-un moment de declin accentuat al interesului pentru structuralismul bazat pe semnificație, declin indus de școala lingvistică nord-americană prin direcțiile poststructuraliste: generativismul și pragmatica. Aceasta este și motivația alegerii limbii engleze pentru acest text, care are un rol de ghid în semantica structurală de la începutul anilor ' 80 .
În cazul unor anumite secțiuni, așa cum este, spre exemplu, prima, cu caracter introductiv (p. 17-18), sînt oferite doar informațiile de bază privind tipurile de semantică (una lingvistică, una a logicienilor și una generală), prin citarea definițiilor date în lucrările reprezentative pentru fiecare tip de semantică.

A doua secțiune (p. 19-29) este un scurt istoric al constituirii acestei discipline în cadrul lingvisticii, în care este discutată în primul rînd distincția dintre semasiologie şi semantică, după care urmează prezentarea diferitelor forme de semantică structurală. Diferențierea cea mai importantă este cea între structuralismul european și cel nord-american, primul centrat pe conținutul lingvistic, cel de-al doilea pe un conținut mai complex, care implică și conținutul rezultat din cunoaşterea prin experiență (prin raportare la realitatea ontică sau la cea situațională), atașat semnificației lexicale în actele de comunicare. O atenție deosebită în acest context i se acordă evoluției direcției mecanicist-behavioriste deschise de Bloomfield, cum de la circumspecția lui Bloomfield privitoare la semnificația lingvistică s-a ajuns la eliminarea acesteia în distribuționalism. Această direcție este descrisă în opoziție cu semantica propusă de antropologi și psihologi (dintre care se remarcă F.G. Lounsbury), aceasta din urmă, prin tenta descriptivă, fiind mai apropiată de lingvistică și, prin urmare, de semantica structurală europeană.

În următoarea secțiune (p. 37-61) sînt prezentate întîi începuturile semanticii structurale bazate pe conținutul lingvistic, concretizată în teoria cîmpurilor semantice (numite mai tîrziu lexicale, pentru că se bazează pe semantica lexicală), reprezentată îndeosebi prin lucrările a doi mari lexicologi germani, Jost Trier şi Leo Weisgerber. Acestora li se adaugă alte concepții despre cîmpul lexical, apărute în perioada postbelică, multe dintre ele în spațiul

*Adresă de corespondență: dinu.moscal@gmail.com. 
lingvisticii franceze, dar şi în spațiul german, saxon și scandinav. Un loc special i se acordă contribuției lui L. Hjelmslev, care a pus bazele semanticii structurale moderne. Propriu-zis, Hjelmslev propune o altă bază pentru analiza unei unități lingvistice: analizei distribuționale îi opune analiza bazată pe proba comutării.

Secțiunea cea mai importantă (p. 63-105) este cea dedicată tipurilor de semantică structurală, abordate în funcție de metodă, fie în direcția de cercetare a școlii nord-americane (distribuția), fie în cea a școlii europene (cumutarea), cu un vizibil accent pe cea de-a doua. După o scurtă prezentare a încercărilor de determinare a conținutului prin metode distribuționale, unde diferitele tipuri de context au un rol determinant, se adaugă un excurs în care este expusă teoria coșeriană a „cadrelor” (sp. „entornos”). Apoi sînt prezentate cunoscutele direcții de analiză structurală a lexicului bazate pe metoda comutării și a identificării trăsăturilor distinctive, începînd cu B. Pottier și continuînd cu A.-J. Greimas, J. Lyons și, în fine, E. Coșeriu, prezentarea în cazul celui din urmă fiind făcută de H. Geckeler, aşa cum se precizează în nota de la titlul textului (p. 15). Desigur, în prezentarea lexematicii lui Coșeriu un rol important îl au cunoscutele distincții preliminare în opoziții binare subordonate succesiv unei entități din distincția anterioară (începînd cu cea dintre realitatea extralingvistică și realitatea lingvistică) prin care se ajunge la lexicul structurabil, obiectul de studiu al lexematicii. Importanța precursorilor lexematicii coșeriene este evidențiată prin citate reprezentative. Excepție face N.S. Trubetzkoy, menționat doar întro notă de subsol (p. 95), care, deși nu a abordat problema semanticii, reprezintă unul dintre pilonii de bază ai lexematicii coșeriene, alături de Hjelmslev.

O scurtă secțiune (p. 107-111) arată evoluția încercărilor de analiză semantică structurală diacronică. J. Trier, cel care a elaborat teoria cîmpurilor semantice, s-a bazat exclusiv pe o analiză diacronică, abordare care se regăsește mai tîrziu și la W. von Wartburg. Coșeriu, beneficiind de instrumentarul analizei semice, elaborează o metodă de analiză semantică din perspectivă sincronică, însă arată cum același instrumentar poate fi utilizat și în analiza semantică diacronică (în principiu, a cîmpurilor lexicale). În realitate, semantica structurală are rădăcini diacronice, iar primul studiu de semantică structurală al lui Coșeriu (Pour une sémantique diachronique structurale, 1964) arată o continuitate în acest sens.

Ultima secțiune (p. 113-116) semnalează posi- bilitățile de cercetare în domeniul semanticii structurale, precum şi cîteva întrebări la care studiile ulterioare ar trebui să răspundă, una dintre acestea fiind posibilitatea unei versiuni complementare a semanticii, în care să se regăsească atît semantica europeană, cît și cea nord-americană.

Traducătorul adaugă la finalul volumului două secțiuni: prima, intitulată Supliment, este un text al lui Coșeriu referitor la statutul lingvistic al semanticii cognitive (apărut în 1992), iar cea de-a doua, intitulată Postfață, este un text în care traducătorul abordează problema conceptului de 'semnificat' la Coșeriu și cea a specificului compuselor românești. Contribuțiile din „postfață” se raportează direct la lexematica lui Coșeriu, însă o postfaţă propriu-zisă ar fi fost mai importantă. O nouă „dare de seamă” după patru decenii de la prima publicare a orientărilor în semantica structurală ar fi arătat în ce măsură direcțiile întrezărite atunci s-au concretizat sau ce alte noi contribuții s-au adus în domeniu, avîndu-se în vedere că preocuparea pentru analiza semantică a lexicului este o constantă în cercetarea lingvistică. Suplimentul atașat poate fi considerat un pas în această direcție, făcut de Coșeriu, ceea ce arată că autorul traducerii este conștient de necesitatea prezentării evoluției ulterioare a semanticii structurale și a impactului la nivelul general al studierii limbajului. Suplimentul constă dintr-un fragment al unei prelegeri a lui Coșeriu din 1992, „Semantica cognitivă și semantica structurală”, şi are în vedere o altă orientare disjunctivă a școlii nord-americane în raport cu structuralismul european, bazat pe semnificația lingvistică. Obiectivul noii direcții de cercetare este cunoașterea clasei de obiecte desemnate prin cuvînt, și nu semnificația prin care cuvîntul trimite către clasa respectivă. În definitiv, diferența dintre structuralismul nord-american şi cel european este dată de perspectiva din care este abordată limba: şcoala nord-americană are ca obiectiv o analiză structurală a limbii printr-o metodă globală, în timp ce școala europeană are ca obiectiv analiza structurală a limbii acolo unde aceasta poate $f i$ analizată din această perspectivă. Ținta fixată de Geckeler și Coșeriu în finalul textului principal al acestui volum presupune combinarea acestor două obiective, însă condiția principală pentru un asemenea pas este unitatea de perspectivă la nivel de metodă, și anume rolul semnificației lingvistice în analiza structurală a limbii. Prezentarea lui Geckeler şi Coșeriu rămîne în continuare un text ce oferă informațiile şi indicaţiile de bază pentru acest obiectiv. 